\title{
EMERGENCY DECLARATIONS AND TRIBES: MECHANISMS UNDER TRIBAL AND FEDERAL LAW
}

Gregory Sunshine and Aila Hoss*

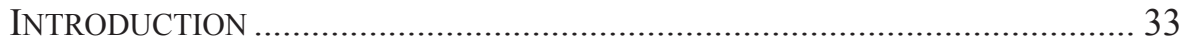

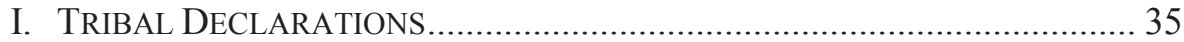

II. STAFFORD ACT DECLARATION REQUESTS ............................................. 39

A.Tribal Request for a Stafford Act Declaration............................... 39

B. State Request for a Stafford Act Declaration............................... 41

III. Federal Public HEALth EMERGENCY DECLARATIONS ...................... 42



\section{INTRODUCTION}

Tribes are sovereign nations that maintain a government-togovernment relationship with the Unites States. ${ }^{2}$ There are currently 567 federally recognized tribes throughout the contiguous United States and Alaska. ${ }^{3}$ As sovereign nations, tribal authority cannot be infringed upon

* Gregory Sunshine, JD and Aila Hoss, JD, serve as Carter Consulting, Inc. contractors with the Public Health Law Program, Office for State, Tribal, Local and Territorial Support, Centers for Disease Control and Prevention, Atlanta, GA. Research conducted for this article was supported by the Oak Ridge Institute for Science and Education. The findings and conclusions in this publication are those of the authors and do not necessarily represent the official position of the Centers for Disease Control and Prevention. This Article should not be construed as providing legal guidance or advice.

2. Cohen's HANDBook of Federal Indian LAW § 4.01(1)(a), at 208 (Nell Jessup Newton et al. eds., 2012).

3. Indian Entities Recognized and Eligible to Receive Services from the United States Bureau of Indian Affairs, 78 Fed. Reg. 26384 (May 6, 2013), available at http://www.gpo.gov/fdsys/pkg/FR-2013-05-06/pdf/2013-10649.pdf; Letter from R. Lee Fleming, Dir., Office of Fed. Acknowledgment, to Kevin Brown (Jul. 2, 2015), available at http://www.bia.gov/cs/groups/public/documents/text/idc1-030829.pdf (regarding final determination for federal acknowledgment of the Pamunkey Indian Tribe on behalf of the Bureau of Indian Affairs and the Department of Interior). See also Final Determination for Federal Acknowledgment of the Pamunkey Indian Tribe, 80 Fed. Reg. 39144 (Jul. 8, 2015), available at 
by states; ${ }^{4}$ however, the U.S. Supreme Court has held that Congress holds the authority to legislate on issues related to tribes and American Indians and Alaska Natives. ${ }^{5}$ The federal government also maintains a trust responsibility towards tribes based on treaties, agreements, statutes, and case law. ${ }^{6}$ This trust responsibility, known as the Trust Doctrine, is "a legally enforceable fiduciary obligation on the part of the United States to protect tribal treaty rights, lands, assets, and resources, as well as a duty to carry out the mandates of federal law with respect to American Indian and Alaska Native tribes and villages."7

In addition to political sovereignty, tribes exercise cultural sovereignty in the form of traditions and religious practices unique to each tribe's own history and culture. " "[C]ultural sovereignty encompasses the spiritual, emotional, mental, and physical aspects" of native people's lives and serves as a foundation to tribal exercise of political sovereignty. ${ }^{9}$

As sovereign nations, tribes have inherent authority to protect the public health and welfare of their citizens and "to make their own laws

https://www.federalregister.gov/articles/2015/07/08/2015-16711/final-determination-forfederal-acknowledgment-of-the-pamunkey-indian-tribe.

4. Williams v. Lee, 358 U.S. 217, 220 (1959). Note that, under certain Public Law 280 exceptions, Congress transferred federal jurisdiction to select states. See 18 U.S.C. $§ 1162$ (2012); 28 U.S.C. $§ 1360$ (2012); 25 U.S.C. $\S \S 1321-1322$ (2012).

5. E.g., Ex Parte Crow Dog, 109 U.S. 556, 567-68, 572 (1883); United States v. Kagama, 118 U.S. 375, 384-85 (1886).

6. Frequently Asked Questions, U.S. DEP'T OF THE INTERIOR, BUREAU OF INDIAN AfFAIRS, http://www.bia.gov/FAQs/index.htm (last updated Oct. 8, 2015) (citing Seminole Nation v. United States, 316 U.S. 286 (1942)).

7. Id.

8. Wallace Coffey \& Rebecca Tsosie, Rethinking the Tribal Sovereignty Doctrine: Cultural Sovereignty and the Collective Future of Indian Nations, 12 STAN. L. \& POL'Y REV. 191, 196 (2001) (arguing that the concept of "cultural sovereignty" needs to be defined by native communities and outside the construct of political sovereignty: "[W]e hope to open a dialogue about sovereignty and our collective future that is generated from within our tribal communities." Id. at 192.). Wallace Coffey is the Chairman of the Comanche Nation Business Committee. Id. at 191. Rebecca Tsosie is a law professor at the Indian Legal Program at Arizona State University. Id. Chairman Coffey and Professor Tsosie previously served on the Board of the Directors of the Native American Rights Fund, which they credited as providing the "impetus for this dialogue on cultural sovereignty." Id.

9. Id. at 209-10. 
and be ruled by them." ${ }^{\prime 10}$ Tribes thus have the authority to undertake measures to prepare and manage public health emergencies in the manner most appropriate for their communities. Coupled with existing federal statutes, there are multiple mechanisms for tribes, either directly or through a state or the U.S. federal government, to declare an emergency or receive the benefits of a federal declaration. ${ }^{11}$ This Article summarizes several types of emergency declarations, including tribal declarations, Stafford Act declarations, and federal public health emergency declarations, and their implications for tribes. ${ }^{12}$

\section{TRIBAL DECLARATIONS}

As sovereign nations, tribes have the authority to declare states of emergency on tribal lands. ${ }^{13}$ This authority may be granted through a tribe's constitution, legal code, or the inherent authority of their governing councils. ${ }^{14}$ Several tribes have exercised their authority to declare emergencies in recent years.

10. Williams, 358 U.S. at 271.

11. See e.g., EAstern BAnd CherokeE Indians CODE § 166-9(a) (2010); NAVAJO NATION Code tit. 2, § 881 (2009); 42 U.S.C. $\S \S 5170(b)(1)-(2), 5191(c)(1)-(2)$ (2012).

12. This Article does not discuss all emergency declarations. Emergency declarations excluded included National Emergencies Act declarations and environmental emergency declarations.

13. See COHEN'S HANDBOOK supra note 2, § 4.01[1][a] (stating that " $\mathrm{t}]$ he right of tribes to govern their members and territories flows from a preexisting sovereignty limited, but not abolished, by their inclusion within the territorial bounds of the United States" and quoting United States v. Wheeler, 435 U.S. 313, 322-323 (1978), which states that tribal "inherent powers of a limited sovereignty... [have] never been extinguished"). Declaring an emergency is an exercise of sovereignty. See LAWRENCE O. Gostin, Public Health Law: Power, Duty, and Restraint 11 (2d ed. 2008) (stating there is an "inherent prerogative of the state to protect and promote the public health, safety, and welfare"). Id. at 20.

14. See, e.g., Constitution of the Standing Rock Sioux Tribe, available at www.standingrock.org/data/upfiles/files/Constitution\%2012-31-09\%20Revised.pdf (last visited Sept. 16, 2014); EASTERn BAND CHEROKEe Indians CODE $§ 166-9$ (a) (2010); Navajo Nation Code tit. 2, § 881 (2009); Oneida Tribe of WI Code $\S 35.8(1)$; Havasupai Tribal Council, Havasupai Resolution No: 26-08, Re: Declaration of EMERGENCY (Aug. 18, 2008), available at www.havasupai-nsn.gov/files/resolutionno.2608.pdf. 
For example, the Standing Rock Sioux Tribe's constitution grants the tribe the power to declare a state of emergency. ${ }^{15}$ On May 27, 2013, the tribe's chairman declared a state of emergency after excessive rainfall caused flash flooding and threatened roads, homes, and the tribe's irrigation system. ${ }^{16}$ The declaration stated that, pursuant to Article IV, Section 1(c)(j)(o) of the tribe's constitution, the tribe has the authority "to safeguard and protect general welfare, property, cultural and natural resources of the Standing Rock Sioux Tribe." ${ }^{\prime 17}$ Because of the threat the floods posed, the chairman authorized all appropriate tribal resources and personnel to respond and directed the tribe to use resources in coordination with federal, state, and local government agencies. ${ }^{18}$ This declaration was ordered to be effective until June 9, 2013, unless extended as necessary. ${ }^{19}$

In another example, the Tribal Business Committee of the Ute Tribe of the Uintah and Ouray Reservation ("the Tribal Business Committee") declared an emergency due to flooding and landslides that occurred on May 20, 2011..$^{20}$ The declaration did not cite a specific provision but stated that the Tribal Business Committee is given authority to declare an emergency by the constitution and bylaws of the tribe. ${ }^{21}$ Floodwater and landslides had damaged infrastructure, homes, cultural sites, and affected oil and gas operations, exhausting most of the Ute Tribe's available

15. Standing Rock Sioux Tribal Flood Emergency Declaration of Disaster, (May 27, 2013), available at

http://srstwater.com/data/upfiles/news/Flood\%20Emergency\%20Declaration\%20of\%20D isaster.pdf (last visited Oct. 29, 2015) [hereinafter Tribal Flood Emergency Declaration]; CONSTITUTION OF THE STANDING Rock SiOUX TRIBE, available at www.standingrock.org/data/upfiles/files/Constitution\%2012-31-09\%20Revised.pdf (last visited Sept. 16, 2014).

16. Tribal Flood Emergency Declaration, supra note 15.

17. Id.; CONSTITUTION OF THE STANDING ROCK SiOUX TRIBE, available at www.standingrock.org/data/upfiles/files/Constitution\%2012-31-09\%20Revised.pdf (last visited Sept. 16, 2014).

18. Tribal Flood Emergency Declaration, supra note 15.

19. Id.

20. Ute Tribal Business Committee, Local "State of Emergency" Disaster DECLARATION, available at www.emergencyinfoutah.com/external/content/document/2515/1106919/1/Ute\%20Tribe \%20emergency\%20declaration\%206-2-11.pdf (last visited Sept. 16, 2014).

21. Id. 
funding and resources. ${ }^{22}$ To prevent further damage and enable recovery, the tribe declared the affected area to be "a disaster requiring aid, assistance and relief available pursuant to the provisions of tribal, state and federal statutes." ${ }^{23}$ The Tribal Business Committee did not give an expiration date for the declaration. ${ }^{24}$

In addition to authority granted by the tribal constitution, some tribes have codified the authority to declare states of emergency and developed procedures for declaring emergencies. For example, under the Cherokee Code of the Eastern Band of the Cherokee Nation,

A State of Emergency shall be deemed to exist whenever during times of public crises, disaster, rioting, catastrophe, or similar public emergency, for any reason, public safety authorities are unable to maintain public order or afford adequate protection for lives, safety or property, or whenever the occurrence of any such condition is imminent. $^{25}$

.. [The code authorizes the Principal Chief] to issue a public proclamation declaring to all persons the existence of such a state of emergency, and, in order to more effectively protect the lives and property of people within the Cherokee Indian trust lands, to place in effect any or all of the restrictions hereinafter authorized. ${ }^{26}$

The Navajo Nation Code establishes a Commission of Emergency Management ("the Commission"), ${ }^{27}$ which is authorized, "[w]ith the concurrence of the President of the Navajo Nation, to declare states of emergency affecting the Navajo Nation or any section thereof." 28 The Commission's other responsibilities include "designat[ing] emergency planning districts in order to facilitate preparation and implementation of emergency plans" and "appoint[ing] a local emergency planning committee for each emergency planning district, and supervise and

22. Id.

23. $I d$.

24. Id.

25. EASTERn BAND CHEROKEe INDIANS CODE $§ 166-9$ (a) (2010).

26. Id. $\S 166-9$ (b).

27. NAvajo Nation CODE tit. 2, § 881 (2009).

28. Id. $\S 884(\mathrm{~B})(1)$. 
coordinate the activities of such committees," among other responsibilities. $^{29}$

Under the Oneida Tribe of Indians of Wisconsin's code, the Oneida Business Committee is "responsible for proclaiming or ratifying the existence of an emergency and for requesting a gubernatorial or presidential declaration." ${ }^{\prime 30}$ If the Oneida Business Committee is not able to proclaim or ratify an emergency declaration, the director of the tribe's Emergency Management/Homeland Security Agency "may proclaim an emergency which shall be in effect until such time the Oneida Business Committee can officially ratify this declaration." ${ }^{31}$ All emergency proclamations expire after thirty days unless renewed by the Oneida Business Committee. ${ }^{32}$

Other tribes rely on the inherent authority of their governing councils to declare states of emergency. In one instance, the Council of the Havasupai Tribe declared an emergency by resolution due to the failure of a dam and high water in nearby creeks, which threatened the tribe's "health, life, safety, and welfare" by destroying trails, leaving visiting campers and residents stranded. ${ }^{33}$ The order did not cite a specific constitutional or statutory provision as providing the Council with the specific authority to declare an emergency. ${ }^{34}$ To aid in response, the tribe

29. Id. § 883(B)(1)-(2).

30. OneIDA TRIBE OF WI Code $\S 35.8(1)$. The tribe's code does not define an emergency or disaster. The Oneida's Emergency Communication Plan Standards defines an emergency/disaster as "[a]ny incident human-caused or natural that requires responsive action to protect life or property. E.g., Tornado, flood, fire, hazardous material spill, bomb, severe weather, aircraft accident, terrorist threat or attack, public health emergencies." Oneida Tribe of Indians of WI, Office of Emergency Management/ Homeland Security, Emergency Disaster Communication Plan Standards, at 2.4 (Nov. 25, 2007) available at

www.oneidanation.org/uploadedFiles/Departments/Emergency_Management/Signed\%20 off $\% 20$ Tribalwide $\% 20$ OEM1\%20.pdf. Note, the Oneida code does provide a definition for "Public Health Emergency" at ONEIDA TRIBE OF WI CODE § 35.3(n); however, this definition applies narrowly and includes only situations involving bioterrorism or biological agents. See ONEIDA TRIBE OF WI CODE § 35.3(n).

31. Id. at $\S 35.8(2)$.

32. Id. at $\S 35.8(5)$.

33. Havasupai Tribal Council, havasupai Resolution No: 26-08, Re: DeCLARATION OF EMERGENCy (Aug. 18, 2008), available at www.havasupai-nsn.gov/files/resolutionno.26-08.pdf.

34. Id. The emergency declaration was adopted at a Special Tribal Council meeting "[p]ursuant to the authority of Article V, Section 1 of the Constitution and By 
requested assistance and support "to the full extent of resources of the United States of America and the State of Arizona." 35 The text of the resolution includes no expiration date. ${ }^{36}$

\section{STAFFORD ACT DECLARATION REQUESTS}

The Robert T. Stafford Disaster Relief and Emergency Assistance Act ("Stafford Act") ${ }^{37}$ authorizes the U.S. President to declare a "major disaster" or "emergency" in response to an event or threat that overwhelms state, tribal, local, or territorial governments. ${ }^{38}$ A Stafford Act declaration triggers access to federal technical, financial, logistical, and other assistance to state, tribal, local, and territorial governments. ${ }^{39}$ Presently, there are two ways a tribe can receive benefits of a Stafford Act declaration: 1) a tribal request for the President to issue a Stafford Act emergency or major disaster declaration or 2) a state governor's request for the President to issue a Stafford Act emergency or major disaster declaration when the tribe's land falls within the requesting state's borders. ${ }^{40}$

\section{A. Tribal Request for a Stafford Act Declaration}

Before 2013, only the governor of an affected state could request a Stafford Act declaration from the President. ${ }^{41}$ Instead, tribes were treated

Laws approved March 27, 1939, and amended on July 22, 1967, June 18, 1968, January 27, 1992, and November 2, 2005." Id.

35. Id.

36. Id.

37. Robert T. Stafford Disaster Relief and Emergency Assistance Act of 1974, Pub. L. No. 93-288, 88 Stat. 143 (codified as amended at 42 U.S.C. $\S \S 5121-5206$ and various sections of titles 12, 16, 20, 26, and 38 of the United States Code).

38. 42 U.S.C. $\S \S 5170(a), 5191(b)$ (2012); Selected Federal Legal Authorities Pertinent to Public Health Emergencies, CENTERS FOR DisEASE CONTROL AND Prevention 1, 2 (Aug. 2014), http://www.cdc.gov/phlp/docs/ph-emergencies.pdf [hereinafter Selected Federal Legal Authorities].

39. $\S \S 5170(a), 5192(a)(1)-(8) ;$ Selected Federal Legal Authorities, supra note 38 , at 2 .

40. $\S \S 5170(\mathrm{~b})(1)-(2), 5191(\mathrm{c})(1)-(2)$.

41. See Jared T. Brown, et. al, Cong. Research Serv., R42991, Analysis of THE SANDY RECOVERY IMPROVEMENT Act OF 20131 (2013), available at 
much like local governments in that they were only able to receive Stafford Act assistance if the governor of the state in which the tribe was located first requested a declaration. ${ }^{42}$ However, under the Sandy Recovery Improvement Act of 2013, the Chief Executive of a tribal government can now follow the same procedures as a state governor to request a Stafford Act declaration from the President. ${ }^{43}$

When requesting a major disaster or emergency declaration under the Stafford Act, the Chief Executive of an affected Indian tribal government must first ensure that "the [situation or disaster] is of such severity and magnitude that effective response is beyond the capabilities of the [tribe] and ... that Federal assistance is necessary." 44 As such, the Chief Executive must take appropriate action to respond to the emergency and activate the tribe's emergency response plan. ${ }^{45}$ Once the tribe's capacity to respond has been exceeded, the Chief Executive must provide information describing the tribe's "efforts and resources which have been or will be used to alleviate the emergency," and must "define the type and extent of Federal aid" the tribe requires to respond to the emergency. ${ }^{46}$ Once the request is submitted, the President alone has the authority to decide whether to issue a Stafford Act declaration. ${ }^{47}$

This legislation now allows tribal governments to directly access Stafford Act benefits that were once available only to the states. ${ }^{48}$ To

https://www.fas.org/sgp/crs/misc/R42991.pdf ("P.L. 113-2 also authorizes tribes to request a declaration of an emergency or major disaster, as was previously only allowed for states.").

42. Selected Federal Legal Authorities, supra note 38, at 2.

43. Sandy Recovery Improvement Act of 2013, Pub. L. No. 113-2, §§ 11011111, 127 Stat. 4, 39, 48 (codified as amended at 42 U.S.C. $\S \S 5170(b)(1), 5191(c)(1)$ (2013)).

44. $\S \S 5170(a), 5191(a)$.

45. $\S \S 5170(a), 5191(a)$.

46. $§ 5191$. See also $§ 5170$.

47. $\S \S 5170,5191$.

48. This is subject to two exceptions; tribes are unable to receive the priority given to states for public facility and public housing assistance funds under 42 U.S.C. $\S$ 5153 (2012) or assistance from Federal Emergency Management Agency's Small State and Rural Advocate under 42 U.S.C. § 5165d (2012). See §§ 5170(b)(2), 5191(c)(2) (“In implementing assistance authorized by the President under this chapter [or subchapter] in response to a request of the Chief Executive of an affected Indian tribal government for $\mathrm{a}$ [n emergency or] major disaster . . ., any reference in this subchapter or subchapter III (except sections 5153 and $5165 \mathrm{~d}$ of this title) to a State or the Governor of a State is 
guide tribes on this new process for requesting declarations, the Federal Emergency Management Agency released Tribal Declarations Pilot Guidance: First Draft in April $2014^{49}$ and conducted listening sessions with tribes through August 2014 to refine the guidance. ${ }^{50}$

The first tribe to exercise the ability to request a Stafford Act declaration was the Eastern Band of Cherokee Indians. ${ }^{51}$ On March 1, 2013, following a request from the tribe's Principal Chief, the U.S. President issued a major disaster declaration for the tribe due to "severe storms, flooding, landslides, and mudslides" that occurred during January 14 to 17,2013 . $^{52}$ As a result, the tribe received more than $\$ 2.4$ million for emergency work, repair or replacement of facilities damaged in the storm, and hazard mitigation measures. ${ }^{53}$

\section{B. State Request for a Stafford Act Declaration}

When granting tribal governments the right to request a Stafford Act declaration for tribal land, Congress included a savings provision to ensure that tribes could still receive aid pursuant to a state-requested declaration. ${ }^{54}$ The law states that "[n]othing in this subsection shall prohibit an Indian tribal government from receiving assistance under this subchapter through a declaration made by the President at the request of a State ... if the President does not make a declaration under this

deemed to refer to an affected Indian tribal government or the Chief Executive of an affected Indian tribal government, as appropriate.").

49. Fed. Emergency Mgmt. Agency, Tribal Declarations Pilot Guidance: FIRST DRAFT 11 (2014), available at www.fema.gov/media-library/assets/documents/93060.

50. Fed. Emergency Mgmt. Agency, Summary of Comments: First Draft of THE Tribal Declarations Pilot Guidance (2015), available at http://www.fema.gov/summary-comments-first-draft-tribal-declarations-pilot-guidance.

51. Eastern Band of Cherokee Indians Get Historical Declaration, FED. EMERgency Mgmt. Agency (Apr. 5, 2013),

www.fema.gov/disaster/4103/updates/easter-band-cherokee-indians-get-historicaldeclaration.

52. Eastern Band of Cherokee Indians; Major Disaster and Related Determinations, 78 Fed. Reg. 17, 422-01 (Mar. 21, 2013).

53. FEMA Assistance Tops \$2 Million in First Tribal Recovery, FED. EMERGENCY Mgmt. Agency (May 10, 2013), www.fema.gov/news-release/2013/05/10/femaassistance-tops-2-million-first-tribal-recovery.

54. 42 U.S.C. $\S \S 5170(b)(3), 5191(c)(3)(2012)$. 
subsection for the same incident." 55 Therefore, while tribal governments now have the right to ask the President to issue a Stafford Act declaration, tribes are not required to submit a request for aid if the state in which a tribe's boundaries fall first requests a declaration.

\section{Federal Public Health Emergency Declarations}

In addition to emergency declarations under the Stafford Act, federal law allows for public health emergency declarations for threats of disease or bioterrorism. Section 319 of the Public Health Service Act provides an additional mechanism that state, tribal, local, and territorial governments can use to facilitate response in the event of a public health emergency. ${ }^{56}$ Section 319 authorizes the Secretary of the Department of Health and Human Services to determine that a public health emergency exists if "1) a disease or disorder presents a public health emergency; or 2) a public health emergency, including significant outbreaks of infectious diseases or bioterrorist attacks, otherwise exists." ${ }^{57}$ The public health emergency declaration is in effect until the Secretary either declares that the emergency no longer exists, or after ninety days, whichever occurs first. ${ }^{58}$ If the Secretary finds that the public health emergency declaration should remain in effect based on the continued existence of the original public health threat or the emergence of new circumstances, he or she may renew the declaration for additional ninety day periods. ${ }^{59}$

A public health emergency declaration gives the Secretary the ability to "take such action as may be appropriate" 60 and to use funds from the Public Health Emergency Fund (when appropriated) to respond to the emergency. ${ }^{61}$ The Secretary can also take actions to directly address the public health emergency, including:

55. Id. $\S 5170(\mathrm{~b})(3)$.

56. 42 U.S.C. $\S 247 \mathrm{~d}(2013)$.

57. Id. $\S 247 \mathrm{~d}(\mathrm{a})(1)-(2)$; see also Selected Federal Legal Authorities, supra note 38 , at 3 .

58. Id.

59. Id.

60. Id. $\S 247 \mathrm{~d}(\mathrm{a})$. at 3 .

61. Id. $\S 247 \mathrm{~d}(\mathrm{a})-(\mathrm{b})$; see also Selected Federal Legal Authorities, supra note 38, 
- waiving or modifying certain Medicare, Medicaid, Children's Health Insurance Program, and Health Insurance Portability and Accountability Act requirements, also known as an "1135 waiver"; 62

- temporarily appointing federal personnel to respond to the public health emergency; and

- under a General Services Administration policy, allowing state, local, tribal, and territorial "government grantees to use federal supply schedules $\left[{ }^{63}\right]$ to respond to public health emergencies."

Further, as amended by the Pandemic and All-Hazards Preparedness Reauthorization Act of 2013, a public health emergency declaration allows the Secretary, upon request by a state governor or tribal organization, ${ }^{65}$ to authorize the temporary reassignment of health

62. 1135 Waivers, U.S. Dep't of Health AND Human Services, OfFice of the Assistant SEC'Y For PREPAREDNESS AND RESPONSE (May 02, 2013),

http://www.phe.gov/Preparedness/legal/Pages/1135-waivers.aspx. In addition to a federal public health emergency declaration, 1135 waivers also require either a federal disaster or emergency declaration under the Stafford Act pursuant to 42 U.S.C. $\S \S 5170$ and 5191 or the National Emergencies Act pursuant to 50 U.S.C. $\S 1601$ et seq. (2012). 42 U.S.C. $\S$ $1320 \mathrm{~b}-5$ (g) (2012).

63. 42 U.S.C. $§ 247 \mathrm{~d}(\mathrm{e})(1)$. Normally, Federal Supply Schedules allow only federal agencies to use a "simplified process for obtaining [commonly used] commercial supplies and services at prices associated with volume buying." See 48 C.F.R. $§ 8.402$ (a) (2014). However, during a federally declared Section 319 Public Health Emergency, state, tribal, local, and territorial governments are permitted to use federal supply schedules to purchase supplies and services "when expending federal grants funds in response to Public Health Emergencies." Public Health Emergencies, U.S. GENERAL SERVICES AdMinistration (OCT. 2, 2015),

www.gsa.gov/portal/content/202565 (providing instructions on the General

Services Administration Public Health Emergency policy).

64. Public Health Emergency Declaration, U.S. DeP'T of HeAlth AND Human Services, Office of the Assistant SeC'y for Preparedness and Response (Nov. 21, 2013), www.phe.gov/Preparedness/legal/Pages/phedeclaration.aspx.

65. 42 U.S.C. $\S 247 \mathrm{~d}(\mathrm{e})(7)(A)$ (citing 25 U.S.C. § 450b(1) (2012). "Tribal organization" is defined as,

$[T]$ he recognized governing body of any Indian tribe; any legally established organization of Indians which is controlled, sanctioned, or chartered by such governing body or which is democratically elected by the adult members of the Indian community to be served by such organization and which includes the maximum participation of Indians in all phases of its activities: Provided, That in any case where a contract is let or grant made to an organization to perform services benefiting more than one Indian tribe, the approval of each such Indian tribe shall be a prerequisite to the letting or making of such contract or grant .... 
department or agency personnel funded in whole or in part through programs authorized under the Public Health Service Act for the purpose of immediately addressing a federally declared public health emergency. ${ }^{66}$ This means that if a tribe faces a federally declared public health emergency, and needs additional public health personnel to aid in response, the tribe can ask the Secretary to authorize the temporary reassignment of federally funded health department personnel to respond.

\section{CONCLUSION}

An emergency declaration can be used as a critical public health tool by authorizing the use of resources and creating exemptions to legal and regulatory requirements that might hinder emergency response. Tribal and federal laws establish mechanisms through which emergencies can be declared on tribal lands, either directly by a tribe or through state or federal governments. This Article reviewed several types of declarations that can be made on tribal lands and the implications of such declarations. Tribes can examine inherent authorities, tribal constitutions, and laws when considering an emergency declaration. 